\title{
PATTERNS OF MORTALITY IN MIDDLE AND EARLY OLD AGE IN THE COUNTY BOROUGHS OF ENGLAND AND WALES
}

\author{
BY \\ M. J. GARDNER, B.Sc., Dip. Math. Stat. \\ M. D. CRAWFORD, M.D. \\ AND \\ J. N. MORRIS, D.Sc., F.R.C.P., D.P.H. (Hon. Director) \\ Medical Research Council's Social Medicine Unit, The London School of Hygiene and Tropical Medicine, Keppel \\ Street, London, W.C.1
}

It is common knowledge that death rates vary from area to area, year to year, and between different groups of the population. These differences have been extensively studied but, very often, only in relation to a particular cause of death or a particular feature of the environment-the association of bronchitis with air pollution, for example, or population density with respiratory death rates. This paper, reporting a fairly comprehensive search for associations between the environment and death rates from four major 'causes' at ages 45-74 in the large towns of England and Wales, has, as its reason, the systematic presentation of some accepted facts and the posing of new, as well as continuing, questions.

\section{MATERIAL}

The data were originally collected to investigate the finding that mortality rates from cardiovascular disease were higher in areas supplied with soft (or acid) drinking water in several very different countries, for example, in Japan (Kobayashi, 1957), the U.S.A. (Schroeder, 1960a, 1960b, 1966), and England and Wales (Morris, Crawford, and Heady, 1961, 1962; Crawford, Gardner, and Morris, 1968a).

In the England and Wales study many other environmental indices were also examined in an attempt to 'explain away' this association. A large amount of data describing environmental characteristics was gathered, a mixture of readily available statistics (for which the County Boroughs are very suitable) together with some specially prepared material. From the censuses we extracted details of population structure, for example of social class composition, density and quality of housing, home ownership, and of intercensal changes in some of these indices. Figures on car licensing from the Ministry of Transport, and specially obtained data on income and unemployment levels, make up a group of socio-economic factors. Also included were measures of air pollution; the provision of general practitioner services, local authority expenditure on provision of child and old people care, schooling; cigarette smoking habits; records of climate; and nature of the local water supplies in a total of almost 80 socio-environmental indices.

At the same time, death rates for all sizeable causes of death in middle age were calculated from unpublished data provided by the General Register Office. We have included death rates for sevenyear periods* around the two latest censuses (1951 and 1961), for each sex, and at ages 45-64 and 65-74, making eight rates for each cause of death per County Borough. A finer breakdown by age is not possible, but we do not believe that differences in age distribution within these ranges could importantly affect the findings.

The 61 County Boroughs having over 80,000 total population in 1961 have now been examined for patterns of mortality from four major 'causes', namely, cardiovascular disease, bronchitis, cancer of lung, and cancer of stomach. The 22 smaller County Boroughs were omitted to reduce errors in estimates of death rates due to small numbers.

\section{RESULTS}

TRENDS AND Ranges of Mortality

The Registrar-General's Decennial Supplements were used for an initial historical study of trends in mortality from all causes. On average the rates in these 61 County Boroughs during this century have fallen similarly to those for the country as a whole. However, there is still substantial variation between

Except for the age-group 65-74 years where the earlier death rates are for $1950-54$. 
TABLE I

MORTALITY FROM ALL CAUSES AT AGES 45-64 IN ENGLAND AND WALES AND IN THE COUNTY BOROUGHS* SINCE 1911

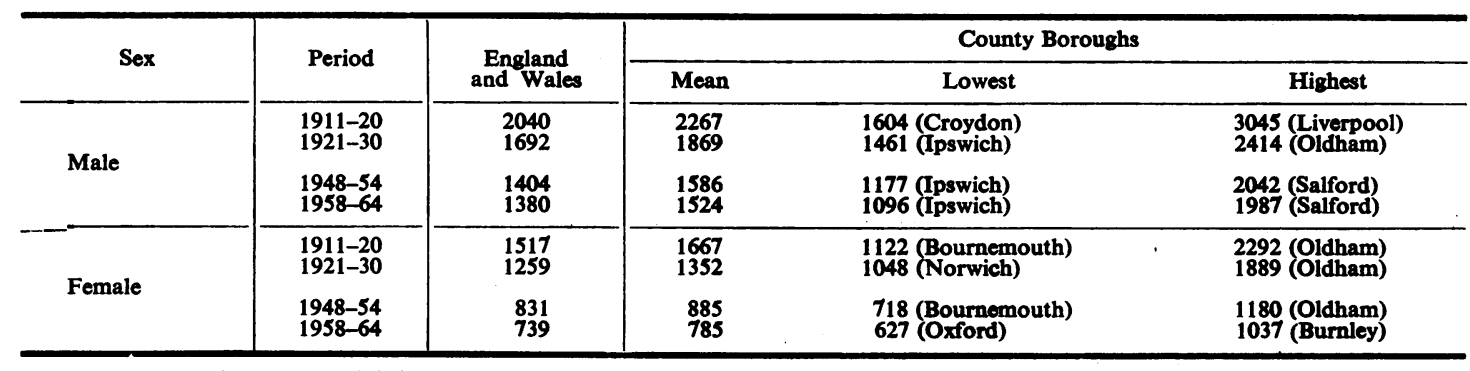

Average annual rates per 100,000 living in age-sex group

61 County Boroughs over 80,000 population in 1961 in all tables

TABLE II

MORTALITY AT AGES 45-64 IN ENGLAND AND WALES AND IN THE COUNTY BOROUGHS DURING 1958-64

\begin{tabular}{|c|c|c|c|c|c|}
\hline \multirow{2}{*}{ Sex } & \multirow{2}{*}{ Certified Cause of Death* } & \multirow{2}{*}{$\begin{array}{l}\text { England } \\
\text { and Wales }\end{array}$} & \multicolumn{3}{|c|}{ County Boroughs } \\
\hline & & & Mean & Lowest & Highest \\
\hline Male & $\begin{array}{l}\text { Cardiovascular disease (17-21) } \\
\text { Bronchitis (24) } \\
\text { Cancer of lung (11) } \\
\text { Cancer of stomach (10) }\end{array}$ & $\begin{array}{r}582 \\
111 \\
178 \\
53\end{array}$ & $\begin{array}{r}673 \\
140 \\
203 \\
60\end{array}$ & $\begin{array}{l}499 \text { (Ipswich) } \\
53 \text { (Ipswich) } \\
150 \text { (Bath) } \\
35 \text { (Bournemouth) }\end{array}$ & $\begin{array}{l}862 \text { (Halifax) } \\
270 \text { (Salford) } \\
292 \text { (Salford) } \\
99 \text { (South Shields) }\end{array}$ \\
\hline Female & $\begin{array}{l}\text { Cardiovascular disease } \\
\text { Bronchitis } \\
\text { Cancer of lung } \\
\text { Cancer of stomach }\end{array}$ & $\begin{array}{r}247 \\
22 \\
24 \\
22\end{array}$ & $\begin{array}{r}310 \\
29 \\
25 \\
26\end{array}$ & $\begin{array}{l}216 \text { (Croydon) } \\
10 \text { (Ipswich) } \\
12 \text { (Doncaster) } \\
11 \text { (York) }\end{array}$ & $\begin{array}{l}453 \text { (Burnley) } \\
59 \text { (Salford) } \\
42 \text { (Brighton) } \\
43 \text { (South Shields, Walsalb }\end{array}$ \\
\hline
\end{tabular}

Average annual rates per 100,000 living in age-sex group.

-Figures in parentheses after cause of death refer to Registrar General's Abridged List

the towns, the same group of towns having consistently experienced low rates, and another group high rates. As an example, Table I gives death rates at $45-64$ years of age.

Concurrently with the falling average death rate, the range of differences between these towns has become smaller, but the highest death rates are consistently just less than double the lowest. Female rates show the expected greater decrease than male; indeed, now, the highest female death rate is similar to the lowest male figure. Thus, during $1958-64$ on average, $1 \%$ of males aged $45-64$ in Ipswich died annually compared with $2 \%$ in Salford; $0.6 \%$ of females at this age in Oxford compared with $1 \%$ in Burnley. A similar picture is found at ages 65-74 years, with the same towns regularly coming at the ends of the ranges*.

Each of the four major causes studied shows similarly large differences between the towns. Table II, again as an example, shows mortality at ages 45-64 during 1958-64.

For separate causes of death somewhat different

* Since 1964 a laree number of boundary changes have meant that recent mortality figures are not comparable to those of earlier periods for some towns. However, the death rates for males aged 45-64 during 1965-67 in Ipswich and Salford, which have not undergone changes, were 1295 and 2004 per 100,000 respectively. towns come at the ends of the ranges, suggesting that different causes were active in different areas.

\section{EnVironmental Associations}

We now turn to the search for associations of mortality with the social and environmental characteristics of the towns. Correlation analysis was used in the initial screening of the large number of indices included for their association, or lack of association, with mortality. We confined our search to environmental factors having consistent associations with cause-specific death rates, bearing in mind other and our own previous work (as will be described, we later probed for possible new associations). It is virtually impossible to start examining a correlation matrix of the size we had, roughly 20,000 coefficients, in any other way, although techniques of cluster analysis could be helpful (Hills, 1969). Indices reflecting four aspects of environment gave consistently high correlations with some or all causes of death (Table III).

First, a collection of indices of bad socio-economic circumstances (and population structure) are positively correlated with mortality. Of the many indices of this type in our available data we have concentrated on nine, representative of the whole, 
TABLE III

CORRELATIONS OF MORTALITY FROM ALL CAUSES DURING 1958-64 WITH LOCAL ENVIRONMENTAL INDICES IN THE COUNTY BOROUGHS

\begin{tabular}{|c|c|c|c|c|}
\hline \multirow{3}{*}{ Environmental Index } & \multicolumn{4}{|c|}{ Sex-age Group } \\
\hline & \multicolumn{2}{|c|}{ Male } & \multicolumn{2}{|c|}{ Female } \\
\hline & $45-64$ & $65-74$ & $45-64$ & $65-74$ \\
\hline \multirow{3}{*}{$\begin{array}{l}\text { Socio-economic indices** } \\
\text { Population density } \\
\text { Overcrowding in } \\
\text { households } \\
\text { Social class } \\
\text { Education } \\
\text { Pre-war unemployment } \\
\text { Income levels } \\
\text { Households per car } \\
\text { \% population aged under } \\
\text { 15 } \\
\text { Migration }\end{array}$} & +0.49 & +0.43 & $+0 \cdot 41$ & +0.35 \\
\hline & $\begin{array}{r}+0.48 \\
+0.55 \\
+0.45 \\
+0.62 \\
+0.60 \\
+0.75\end{array}$ & $\begin{array}{r}+0.44 \\
+0.64 \\
+0.58 \\
+0.50 \\
+0.66 \\
+0.66\end{array}$ & $\begin{array}{r}+0.32 \\
+0.48 \\
+0.43 \\
+0.55 \\
+0.50 \\
+0.72\end{array}$ & $\begin{array}{r}+0.31 \\
+0.57 \\
+0.62 \\
+0.45 \\
+0.68 \\
+0.60\end{array}$ \\
\hline & $\begin{array}{r}+0.40 \\
+0.48\end{array}$ & $\begin{array}{r}+0.53 \\
+0.51 \\
\end{array}$ & $\begin{array}{l}+0.31 \\
+0.36\end{array}$ & $\begin{array}{r}+0.46 \\
+0.44\end{array}$ \\
\hline $\begin{array}{l}\text { Air pollution } \\
\text { 'Domestic' air pollution* } \\
\text { Smoket } \\
\text { SO } t \text { - }\end{array}$ & $\begin{array}{l}+0.74 \\
+0.48 \\
+0.53\end{array}$ & $\begin{array}{l}+0.67 \\
+0.45 \\
+0.51\end{array}$ & $\begin{array}{l}+0.57 \\
+0.37 \\
+0.39\end{array}$ & $\begin{array}{l}+0.56 \\
+0.42 \\
+0.40\end{array}$ \\
\hline $\begin{array}{l}\text { Climate } \\
\text { Latitude } \\
\text { Sunshinef } \\
\text { Temperaturef } \\
\text { Rainfall } \neq\end{array}$ & $\begin{array}{l}+0.65 \\
-0.53 \\
-0.54 \\
+0.52\end{array}$ & $\begin{array}{l}+0.58 \\
-0.61 \\
-0.53 \\
+0.38\end{array}$ & $\begin{array}{r}+0.53 \\
-0.55 \\
-0.54 \\
+0.61\end{array}$ & $\begin{array}{r}+0.60 \\
-0.73 \\
-0.67 \\
+0.44\end{array}$ \\
\hline $\begin{array}{l}\text { Water supplies } \S \\
\text { Total hardness } \\
\text { Calcium content }\end{array}$ & $\begin{array}{l}-0.55 \\
-0.66\end{array}$ & $\begin{array}{l}-0.59 \\
-0.64\end{array}$ & $\begin{array}{l}-0.58 \\
-0.65\end{array}$ & $\begin{array}{l}-0.58 \\
-0.65\end{array}$ \\
\hline
\end{tabular}

For normally distributed variables these are the significance levels of the product moment correlation coefficient ( $r$ ) for 61 pairs of observations:

$$
\mathrm{r}<-0.33 \text { or } \mathrm{r}>+0.33: \mathrm{P}<0.01
$$

* See Table IV for fuller description and references.

-Daly (1959).

†Department of Scientific \& Industrial Research (1964)

ILong period averages; for years 1921-50 for sunshine and temperature, for years 1916-50 for rainfall. Meteorological Office personal communication

$\S$ See Appendix

showing the highest correlations with the death rates. Thus, the densely populated towns with their excess proportions in the low social class and income groups, with higher unemployment and lower car ownership, from which people migrate, classically have higher mortality rates. Two interesting features here are the younger age distributions of these disadvantaged towns and the very high correlations with mortality of a recent index of economic status - the number of households per car. The greater this ratio, the fewer the cars owned by the local population and the higher were the death rates. It could be that this index, in an age when a motor car still is something of a status symbol, but a major expense, is an explicit measure of living standards in general.

These various indices are, of course, highly intercorrelated and each can be thought of as reflecting to some degree the general social and economic conditions of the towns over the past 30 years. Consequently, and as each gave similar results in further analyses, they were combined into a single index. We used principal component analysis including the nine indices, and the first component, explaining $67 \%$ of the total variation of these indices between towns, we have taken to give a 'social factor score' for each town (see Appendix).

TABLE IV

CORRELATIONS OF SOCIO-ECONOMIC INDICES WITH THE 'SOCIAL FACTOR SCORE'

\begin{tabular}{|c|c|}
\hline Socio-economic Index & $\begin{array}{l}\text { Correlation } \\
\text { Coefficient } \\
\text { (r) }\end{array}$ \\
\hline $\begin{array}{l}\text { 1. Persons per acre of built-up area, } 1951^{*}+ \\
\text { 2. \% of households with more than } 1 \frac{1}{2} \text { persons per } \\
\text { room, } 1951^{*} \\
\text { 3. Social class index, } 1951^{*}+ \\
\text { 4. \% of occupied males who left school under } 15 \text { years } \\
\text { of age, } 1951^{*} \\
\text { 5. Average \% unemployed, } 1927-38 * * \\
6 \text { \% earning under } £ 710 \text { s. Od., } 1950 t \\
\text { 7. Average number of households per car, } 1961 \% \S \\
\text { 8. \% population aged under } 15 \text { years, } 1961^{*} \\
1951-61 *\end{array}$ & $\begin{array}{l}+0.79 \\
+0.78 \\
+0.90 \\
+0.68 \\
+0.74 \\
+0.87 \\
+0.79 \\
+0.74 \\
+0.69\end{array}$ \\
\hline
\end{tabular}

-Registrar-General, Census, 1951 or 1961

+Daly (1959)

Wilkins (1952)

$\$$ Ministry of Transport (1961)

* Morris and Titmuss (1944)

Table IV shows the indices included, and that each has a correlation of +0.68 or more with this social factor score (the 'social factor score' is a weighted linear combination of the nine indices, the weights being proportional to the correlations of Table IV). A similar approach was used by Buckatzsch (1947) in looking at the relationship between infant mortality rates and social conditions.

Secondly, indices of air pollution are highly associated with death rates. The index of 'domestic' air pollution, derived from coal bought for consumption on domestic fires (Daly, 1959), gave the highest correlation with mortality and was mainly used. The smoke and $\mathrm{SO}_{2}$ figures from the National Survey of Air Pollution were not available at comparable sites for all the towns, but, where we could extract figures, they were similar to those of Buck and Brown (1964) and gave expected correlations. However, although Daly's index is very highly correlated with the group of social indices (as a measure of air pollution has to be almost by definition in this country), it seems also to contain a specific pollution measure, and is more applicable to the mortality period studied when few actual measurements of air pollution were available. We hope to make further use of the National Survey data when these have been standardized to allow valid comparison between towns.

Thirdly, climatic factors are correlated with death rates. That mortality is higher in the north is well 
known, presumably reflecting climatic (mainly temperature and sunshine) and also social-industrial conditions.

Fourthly, measures of the hardness of local drinking water supplies show strong negative correlations with mortality (the softer the local drinking water, the higher the death rates). The concentration of calcium ion in water gives the highest correlation with mortality, and can be precisely estimated (see Appendix).

\section{Multiple Regression AnAlysis}

We then used multiple regression analysis with each of the death rates from all causes and specific causes in turn as the dependent variable, and four environmental factors (the social factor score, 'domestic' air pollution, latitude, and water calcium) as the independent variables. The ordinary linear additive model was used attempting to explain absolute differences in rates; other approaches by transforming the dependent and independent variables were tried but gave similar results.

The variance of each death rate between the towns unexplained by these four factors was then examined to see whether any further environmental factors should be included. The only factors showing sizeable and consistent correlations with the residuals (a residual is the difference between the observed death rate and that predicted from the regression equation containing the four factors) were long period average rainfall and longitude, those with rainfall being higher, for all causes of death and specifically for cardiovascular disease. These two indices are, of course, highly associated-more rainfall on the west coast and vice versa-and rainfall only was thus included in the multiple regression equations.

A repeat examination of the now unexplained variance showed no important independent contribution for any of the causes of death from any other environmental index for which we have data; nor was there any evidence of important departures from the model for the five factors now included. The final multiple regression equations for death rates from all causes, cardiovascular disease, bronchitis, cancer of lung, and cancer of stomach are given in Table $\mathrm{V} a, b, c, d$ and $e$; all the five independent variables have been left in each equation, even if not significant, to show the patterns that emerge.

The analysis can be considered as giving the best estimate of each death rate as a linear combination of these five environmental factors, the importance of any factor for a particular rate being indicated by the size and significance of its coefficient. Standardized partial regression coefficients are shown in
Table $\mathrm{V}$ to enable comparison across rows and down columns. For example, the first row shows the relationships of the indices to male mortality at ages 45-64 during 1948-54 from all causes-air pollution, rainfall, and water calcium making significant independent contributions to the explanation of variance in that order. Briefly, the pattern for specific causes of death is as follows-latitude, rainfall, and water calcium are associated with cardiovascular disease (broadly similar associations are found for each of the two major components of cardiovascular disease, i.e., coronary heart disease and cerebrovascular disease); all the indices except, surprisingly, latitude show significant coefficients in bronchitis; the air pollution index is associated with lung cancer; the social factor score is associated with stomach cancer.

The proportion of the variance of death rates between the towns that is explained by the linear combinations of these factors is given in the final column of Table V. This percentage is notably high for mortality from all causes, reaching $84 \%$ (or, equivalently, a multiple correlation coefficient of 0.92 ) for the recent rate in middle-aged men. On average, about $70 \%$ of the variance in cardiovascula mortality is explained, for bronchitis about $60 \%$ for cancer of stomach and for cancer of lung it males about $50 \%$-showing a differential ability of the environmental factors to explain differences in the various causes of death.

\section{Discussion}

This study has shown that there are substantial differences of death rates, among the middle and early old aged population, between the large towns in England and Wales; these differences are associated with local environmental factors, differently however for the various causes of death. However, it is important to realize that these analyses are concerned with studying mortality variations between the towns, and may give clues to aetiological factors in the environment, and do not deal with individual risk factors. Thus, if the populations of two towns have the same cigarette smoking habits, differences in their lung cancer death rates will reflect differences in causally related environmental conditions, but there is no doubt what is the main cause of the disease among the individuals of each town. Identification of subgroups of the population of towns similar in both relevant personal and environmental characteristics is likely to raise the explanation of variance of mortality between these subgroups. For example, grouping males by cigarette smoking and morning cough habits in areas of varying urbanization, Buck and Wicken (1967) achieved 
TABLE V

MULTIPLE REGRESSION† OF LOCAL DEATH RATES ON FIVE SOCIO-ENVIRONMENTAL INDICES IN THE COUNTY BOROUGHS

\begin{tabular}{|c|c|c|c|c|c|c|c|}
\hline Sex-age Group & Period & $\begin{array}{l}\text { Social } \\
\text { Factor } \\
\text { Score }\end{array}$ & $\begin{array}{l}\text { 'Domestic' } \\
\text { Air } \\
\text { Pollution }\end{array}$ & Latitude & $\begin{array}{l}\text { Water } \\
\text { Calcium }\end{array}$ & $\begin{array}{l}\text { Long Period } \\
\text { Average } \\
\text { Rainfall }\end{array}$ & $\begin{array}{c}\text { \% of } \\
\text { Variance } \\
\text { Explained }\end{array}$ \\
\hline $\begin{array}{l}\text { (a) All Causes } \\
\text { Males 45-64 }\end{array}$ & $\begin{array}{l}1948-54 \\
1958-64\end{array}$ & $\begin{array}{l}+0 \cdot 16 \\
+0 \cdot 19\end{array}$ & $\begin{array}{l}+0.48 \% \\
+0.36 \%\end{array}$ & $\begin{array}{l}+0.10 \\
+0.21\end{array}$ & $\begin{array}{l}-0.23 * \\
-0.24 \%\end{array}$ & $\begin{array}{l}+0.27 \ldots 0 \\
+0.30\end{array}$ & $\begin{array}{l}80 \\
84\end{array}$ \\
\hline Males 65-74 & $\begin{array}{l}1950-54 \\
1958-64\end{array}$ & $\begin{array}{l}+0.24 \% \\
+0.39 \%\end{array}$ & $\begin{array}{l}+0.28 * \\
+0.17\end{array}$ & $\begin{array}{l}+0.02 \\
+0.13\end{array}$ & $\begin{array}{l}-0 \cdot 43 * * * \\
-0 \cdot 30 * \%\end{array}$ & $\begin{array}{l}+0 \cdot 17 \\
+0 \cdot 21\end{array}$ & $\begin{array}{l}73 \\
76\end{array}$ \\
\hline Females 45-64 & $\begin{array}{l}1948-54 \\
1958-64\end{array}$ & $\begin{array}{l}+0.16 \\
+0.29 *\end{array}$ & $\begin{array}{l}+0 \cdot 20 \\
+0 \cdot 12\end{array}$ & $\begin{array}{l}+0 \cdot 32 * \\
+0 \cdot 19\end{array}$ & $\begin{array}{l}-0 \cdot 15 \\
-0 \cdot 22\end{array}$ & $\begin{array}{l}+0.40 * * * \\
+0.39 * * *\end{array}$ & $\begin{array}{l}73 \\
72\end{array}$ \\
\hline Females $65-74$ & $\begin{array}{l}1950-54 \\
1958-64 \\
\end{array}$ & $\begin{array}{l}+0.39 \cdots * \\
+0.40 \% \\
\end{array}$ & $\begin{array}{r}+0.02 \\
-0.05 \\
\end{array}$ & $\begin{array}{l}+0.36 \cdots \\
+0.29 \% \\
\end{array}$ & $\begin{array}{l}-0.12 \\
-0.27 \cdots\end{array}$ & $\begin{array}{l}+0.40 \cdots \cdots \\
+0.29 \cdots \\
\end{array}$ & $\begin{array}{l}80 \\
73 \\
\end{array}$ \\
\hline $\begin{array}{l}\text { (b) Cardiovascular } \\
\text { Disease } \\
\text { Males 45-64 }\end{array}$ & $\begin{array}{l}1948-54 \\
1958-64\end{array}$ & $\begin{array}{l}-0 \cdot 32 * \\
-0 \cdot 17\end{array}$ & $\begin{array}{l}+0.25 * \\
+0.28\end{array}$ & $\begin{array}{l}+0.39 \cdots \\
+0.31 \%\end{array}$ & $\begin{array}{l}-0 \cdot 30 \cdots \\
-0 \cdot 29 \cdots\end{array}$ & $\begin{array}{l}+0.5000 \\
+0.48 .6\end{array}$ & $\begin{array}{l}75 \\
74\end{array}$ \\
\hline Males 65-74 & $\begin{array}{l}1950-54 \\
1958-64\end{array}$ & $\begin{array}{r}-0.12 \\
+0.07\end{array}$ & $\begin{array}{l}-0.01 \\
-0.04\end{array}$ & $\begin{array}{l}+0.40 \% * \\
+0.29 \%\end{array}$ & $\begin{array}{l}-0.44 * \cdots \\
-0.35 * \%\end{array}$ & $\begin{array}{l}+0.31 * \\
+0.41 \%\end{array}$ & $\begin{array}{l}66 \\
66\end{array}$ \\
\hline Females 45-64 & $\begin{array}{l}1948-54 \\
1958-64\end{array}$ & $\begin{array}{l}+0.14 \\
+0.18\end{array}$ & $\begin{array}{l}+0.09 \\
+0.10\end{array}$ & $\begin{array}{l}+0.39 * * \\
+0.31 *\end{array}$ & $\begin{array}{l}-0.22 * \\
-0.25 *\end{array}$ & $\begin{array}{l}+0.41 * \ldots \\
+0.44 \% *\end{array}$ & $\begin{array}{l}75 \\
78\end{array}$ \\
\hline Females $65-74$ & $\begin{array}{l}1950-54 \\
1958-64 \\
\end{array}$ & $\begin{array}{l}+0.24 \\
+0.33 * \\
\end{array}$ & $\begin{array}{l}-0.08 \\
-0.22 \\
\end{array}$ & $\begin{array}{l}+0.54 \% * \\
+0.45 * \% \\
\end{array}$ & $\begin{array}{l}-0.05 \\
-0.26\end{array}$ & $\begin{array}{l}+0.48 * * * \\
+0.34 * 6 * \\
\end{array}$ & $\begin{array}{l}73 \\
70 \\
\end{array}$ \\
\hline $\begin{array}{l}\text { (c) Bronchitis } \\
\text { Males 45-64 }\end{array}$ & $\begin{array}{l}1948-54 \\
1958-64\end{array}$ & $\begin{array}{l}+0.23 \\
+0.29\end{array}$ & $\begin{array}{l}+0.48 * * * \\
+0.32 *\end{array}$ & $\begin{array}{l}+0.07 \\
+0.14\end{array}$ & $\begin{array}{l}-0 \cdot 14 \\
-0.26\end{array}$ & $\begin{array}{l}+0 \cdot 18 \\
+0 \cdot 11\end{array}$ & $\begin{array}{l}70 \\
70\end{array}$ \\
\hline Males 65-74 & $\begin{array}{l}1950-54 \\
1958-64\end{array}$ & $\begin{array}{l}+0.35^{\circ} \\
+0.33^{\circ}\end{array}$ & $\begin{array}{l}+0.377^{\circ} \\
+0.31\end{array}$ & $\begin{array}{r}-0.16 \\
+0.02\end{array}$ & $\begin{array}{l}-0 \cdot 28 * \\
-0 \cdot 20\end{array}$ & $\begin{array}{l}+0.03 \\
+0.14\end{array}$ & $\begin{array}{l}54 \\
57\end{array}$ \\
\hline Females 45-64 & $\begin{array}{l}1948-54 \\
1958-64\end{array}$ & $\begin{array}{l}+0.07 \\
+0.22\end{array}$ & $\begin{array}{l}+0.49 \% \\
+0.33^{\circ}\end{array}$ & $\begin{array}{l}+0.12 \\
+0.19\end{array}$ & $\begin{array}{l}-0.06 \\
-0.09\end{array}$ & $\begin{array}{l}+0.37 \% \\
+0.27 \bullet\end{array}$ & $\begin{array}{l}62 \\
61\end{array}$ \\
\hline Females $65-74$ & $\begin{array}{l}1950-54 \\
1958-64 \\
\end{array}$ & $\begin{array}{l}+0 \cdot 19 \\
+0 \cdot 19 \\
\end{array}$ & $\begin{array}{l}+0.31 \\
+0.40 \\
\end{array}$ & $\begin{array}{r}+0.08 \\
+0.04 \\
\end{array}$ & $\begin{array}{l}-0 \cdot 15 \\
-0 \cdot 19\end{array}$ & $\begin{array}{l}+0.25 * \\
+0.16 \\
\end{array}$ & $\begin{array}{l}49 \\
53 \\
\end{array}$ \\
\hline $\begin{array}{l}\text { (d) Cancer of Lung } \\
\text { Males 45-64 }\end{array}$ & $\begin{array}{l}1948-54 \\
1958-64\end{array}$ & $\begin{array}{l}+0.12 \\
+0.32\end{array}$ & $\begin{array}{l}+0.71 \% * \% \\
+0.53 \%\end{array}$ & $\begin{array}{l}-0 \cdot 46 \% \\
-0 \cdot 10\end{array}$ & $\begin{array}{l}-0.02 \\
-0.08\end{array}$ & $\begin{array}{l}-0 \cdot 07 \\
-0 \cdot 18\end{array}$ & $\begin{array}{l}39 \\
58\end{array}$ \\
\hline Males $65-74$ & $\begin{array}{l}1950-54 \\
1958-64\end{array}$ & $\begin{array}{r}-0 \cdot 12 \\
+0 \cdot 19\end{array}$ & $\begin{array}{l}+0.87 \cdots * \\
+0.68 * \omega *\end{array}$ & $\begin{array}{l}-0.55 \% \\
-0.43 \%\end{array}$ & $\begin{array}{l}-0 \cdot 11 \\
-0.21\end{array}$ & $\begin{array}{l}-0.31 * \\
-0.45 * *\end{array}$ & $\begin{array}{l}41 \\
54\end{array}$ \\
\hline Females 45-64 & $\begin{array}{l}1948-54 \\
1958-64\end{array}$ & $\begin{array}{r}+0.03 \\
-0.25\end{array}$ & $\begin{array}{l}+0.49 * \\
+0.64 \%\end{array}$ & $\begin{array}{l}-0 \cdot 27 \\
-0 \cdot 10\end{array}$ & $\begin{array}{r}-0.17 \\
+0.07\end{array}$ & $\begin{array}{l}-0.12 \\
-0.09\end{array}$ & $\begin{array}{l}19 \\
18\end{array}$ \\
\hline Females $65-74$ & $\begin{array}{l}1950-54 \\
1958-64\end{array}$ & $\begin{array}{l}+0.08 \\
-0.06\end{array}$ & $\begin{array}{l}+0.61 \% \\
+0.25 \\
\end{array}$ & $\begin{array}{r}-0.21 \\
-0.04 \\
\end{array}$ & $\begin{array}{r}+0.13 \\
+0.27 \\
\end{array}$ & $\begin{array}{l}-0.09 \\
-0.25\end{array}$ & $\begin{array}{l}31 \\
22 \\
\end{array}$ \\
\hline $\begin{array}{l}\text { (e) Cancer of Stomach } \\
\text { Males 45-64 }\end{array}$ & $\begin{array}{l}1948-54 \\
1958-64\end{array}$ & $\begin{array}{l}+0.30 \\
+0.45\end{array}$ & $\begin{array}{l}+0.40 * \\
+0.40 *\end{array}$ & $\begin{array}{l}-0.08 \\
-0.08\end{array}$ & $\begin{array}{r}-0.12 \\
+0.14\end{array}$ & $\begin{array}{l}+0.18 \\
+0.35 \%\end{array}$ & $\begin{array}{l}52 \\
65\end{array}$ \\
\hline Males 65-74 & $\begin{array}{l}1950-54 \\
1958-64\end{array}$ & $\begin{array}{l}+0.48 \% \\
+0.43^{\circ}\end{array}$ & $\begin{array}{l}+0.06 \\
+0.37\end{array}$ & $\begin{array}{r}+0 \cdot 25 \\
-0 \cdot 12\end{array}$ & $\begin{array}{l}+0.11 \\
+0.12\end{array}$ & $\begin{array}{l}+0 \cdot 28 * \\
+0 \cdot 23\end{array}$ & $\begin{array}{l}54 \\
49\end{array}$ \\
\hline Females 45-64 & $\begin{array}{l}1948-54 \\
1958-64\end{array}$ & $\begin{array}{l}+0.28 \\
+0.63\end{array}$ & $\begin{array}{r}+0.11 \\
-0.03\end{array}$ & $\begin{array}{l}-0.35 \\
+0.11\end{array}$ & $\begin{array}{l}+0.08 \\
+0.10\end{array}$ & $\begin{array}{l}+0.25 \\
+0.22\end{array}$ & $\begin{array}{l}46 \\
48\end{array}$ \\
\hline Females $65-74$ & $\begin{array}{l}1950-54 \\
1958-64\end{array}$ & $\begin{array}{l}+0.48 * * \\
+0.51 *\end{array}$ & $\begin{array}{r}-0.04 \\
+0.16 \\
\end{array}$ & $\begin{array}{l}+0.30 \\
-0.08\end{array}$ & $\begin{array}{l}+0.07 \\
+0.01\end{array}$ & $\begin{array}{l}+0.37 \% \\
+0.30^{*}\end{array}$ & $\begin{array}{l}56 \\
48\end{array}$ \\
\hline
\end{tabular}

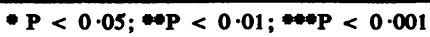

tStandardized partial regression coefficients given, $i$.e., the variables are reduced to the same mean (zero) and variance (one), to allow values for the five socio-environmental indices in each cause of death to be compared. The higher of two coefficients is not necessarily the more significant statistically.

over $90 \%$ explanation of the variance of lung cancer and bronchitis mortality between these groups, compared to our $39-70 \%$ between towns. The degree of implication of (lack of) water calcium as a 'cause' of cardiovascular mortality similarly would require knowledge of the distribution of personal risk factors, such as diet and physical activity, in the towns. For each disease dealt with here, however, the large range of mortality between the towns indicates a real possibility of environmental factors being causal. Thus, interpretation of the associations described requires a deal of care. 
We have attempted to search out from the information at hand all environmental indices that consistently relate to particular causes of death. In using the multiple regression approach, and including all environmental factors which were significantly associated with differences in mortality between the towns, some interesting findings emerged. The one of particular relevance to the original study is the suggestion that rainfall adds markedly to the explanation of cardiovascular mortality variance between the towns. Rainfall is highly correlated $(r=-0.6)$ with water calcium, and it was thought that its inclusion in the regression would not add anything extra or new. However, the increasing facilities for computer handling of large-scale data of this type have enabled the testing out of some thoughts that had to remain as such a short while ago. Again, it is interesting how air pollution and the social factor score, also being highly intercorrelated $(\mathrm{r}=+0 \cdot 8)$, show consistently different and expected relationships with mortality.

The association with rainfall, however, is perplexing. Is it reflecting some climatic or geographical influence not yet considered, or is the long-period average rainfall a better index of long-term local mineral differences in soil and water? Takahashi (1967) has shown a relationship between cerebrovascular mortality and age of the main rock strata within several European countries, and suggested that leeching of minerals by rainfall from the strata may be relevant. A group in Michigan, analysing U.S.A. mortality data, have proposed that 'chronic environmental discomfort (if not actual stress) is in some way associated with the development of coronary heart disease' (Dudley, Beldin, and Johnson, 1969). They find a climatic 'comfort index'-combining levels of relative humidity and temperature-highly negatively correlated with mortality from coronary heart disease, and more important than water hardness in predicting the death rate. Temperature and relative humidity do not have the same large range in this country as in the U.S.A., but their findings are not dissimilar to ours in indicating a climatic factor (rainfall, plus the climatic component of latitude reflecting temperature and sunshine). We are hoping to follow this finding through in collaboration with meteorologists as well as water and soil chemists.

The findings for bronchitis, whilst not identifying any overwhelming factor associated with differences in local mortality rates, do nevertheless consistently indicate the known relationships with air pollution, bad social conditions, and inclement climate (Buck and Brown, 1964; Daly, 1959; Fairbairn and Reid, 1958). The association with the air pollution index is stronger at age 45-64 than in the older group. This may be real or may be related to the higher accuracy of certification of bronchitis in younger deaths.

Stocks $(1960,1966,1967)$ has reported an association of air pollution with cancer of the lung both within and between countries. This association seems to be greater for males, for whom the death rates are much higher. One factor which cannot be excluded when discussing lung cancer (or bronchitis) is, of course, cigarette smoking! The two indices we had of smoking levels in these towns were for recent years (Morris, 1964; Tobacco Research Council) and, not surprisingly, showed no association with the lung cancer mortality rates, as probably the relevant figures would be smoking levels in the 1940 s or earlier for the death rates used $\omega$ here. There is some evidence (Hulton Readership Survey, 1948) that some 20 years ago cigarette consumption was higher in the south than in the $\frac{\text { s }}{2}$ north, but that now the position has been reversed; $\rightarrow$ the negative association with latitude, greater around 1951 than around 1961, possibly is a reflection of this trend.

An association between cancer of stomach deat $\vec{\varphi}$ rates and poor living conditions has long bee of known (Registrar-General, 1938; Stocks, 194落 1960) and, as expected, the social factor score has significant relationship. Air pollution is independently associated with death rates in three of the male groups; this may indicate a causative factor and supports the suggestion by Stocks (1962) that hydrocarbons in the air might be important, particularly in men in certain occupations. Rainfall shows a consistent association, and this reflects the known geographic distribution of gastric cancer mortality in this country.

Throughout the discussion the positive findings have been highlighted. However, it is equally important to comment, in terms of describing the patterns of mortality that have emerged, where no associations have been found. Thus, for example, air pollution shows no consistent relationship with cardiovascular mortality, nor water calcium with $\frac{D}{0}$ stomach cancer, nor the social factor score with lung cancer, emphasizing the specific (or stronger) $N$ associations between environmental factors and particular causes of death.

There are many questions unanswered which this study only helps to pose. How relatively important are the environmental factors in younger or older ages, or in the different sexes-are their effects greater in individuals with adverse personal risk factors? How do time trends in the death rates relate to changing environmental conditions, for 
example since the Smoke Control Act? To what extent does inter-town migration in itself create differences in mortality? We need to know to what extent it is that the healthier (richer, progressive) or less healthy leave the north for the south. Do morbidity statistics give the same pattern?

We did not include many indices of local health and welfare services, but a report commissioned by the Royal Commission on Local Government (1968) suggests little relationship between services and need, though Davies (1968) indicates this is not so for all services. However, average general practitioner list size in the towns showed no correlation with mortality from any cause in this study, and it is noteworthy that such an imbalance exists between services and need after so many (more than 50) years of consistent mortality differences. Meanwhile, mortality differentials persist, and are associated with changing, changeable, and unchangeable aspects of town environment.

\section{SUMmaRY}

A study is described of male and female mortality at ages 45-74 years in the larger County Boroughs of England and Wales. Death rates are looked at in relation to changes that have occurred during this century, and to environmental indices associated with the differences between these towns in death rates from four main causes of death-namely, cardiovascular disease, bronchitis, cancer of lung, and cancer of stomach.

The ranking of these towns by their death rates from all causes is similar during each of four periods in the last 50 years, those towns with lower or higher rates remaining so. The highest age-sex specific death rate remains nearly twice the lowest, i.e., there are still substantial differences between towns in mortality.

Indices reflecting five aspects of local environment are shown to explain a large percentage of the variance of the death rates between towns. These are socio-economic conditions, air pollution, latitude, hardness of water supplies, and longperiod average rainfall. Multiple regression methods are used to show how these indices are differently related to each cause of death at these ages.

We thank the General Register Office, the Meteorological Office, the water authorities of the County Boroughs and their chief officers, and the Tobacco Manufacturers Standing Committee.

Mrs. R. Glass and Mr. W. Scott of the Centre for Urban Studies kindly provided us with abstracts of census data; Dr. M. Clifton of Warren Spring Laboratory gave useful advice on air pollution measurement, while Mr. R. Waller helpfully commented on an earlier version.

We are also grateful to many colleagues in the M.R.C. Social Medicine Unit, in particular to Dr. J. A. Heady, for advice and assistance.

\section{REFERENCES}

Buck, S. F., and Brown, D. A. (1964). Tobacco Research Council Research Papers No. 7. Mortality from lung cancer and bronchitis in relation to smoke and sulphur dioxide concentration, population density and social index.

— and WiCKEN, A. J. (1967). Models for use in investigating the risk of mortality from lung cancer and bronchitis. Appl. Statist., 16, 185.

BucKatzsch, E. J. (1947). The influence of social conditions on mortality rates. Population Studies, $1,229$.

CraWford, M. D., Gardner, M. J., and Morris, J. N. (1968a). Mortality and hardness of local watersupplies. Lancet, $1,827$.

,,$---(1968 \mathrm{~b})$. Mortality and hardness of water. Ibid., 1, 1092.

DaLY, C. (1959). Air pollution and causes of death. Brit. J. prev. soc. Med., 13, 14.

DAVIES, B. (1968). Social Needs and Resources in Local Services. Joseph, London.

DeParTMENT OF SCIENTIFIC AND INDUSTRIAL RESEARCH (now Ministry of Technology). Warren Spring Laboratory, Stevenage; and unpublished data. Atmospheric Pollution Bulletin, Section 1, for March 1964.

Dudley, E. F., Beldin, R. A., and Johnson, B. C. (1969). Climate, water hardness and coronary heart disease. J. chron. Dis. In press.

FAIRBAIRN, A. S., and ReID, D. D. (1958). Air pollution and other local factors in respiratory disease. Brit. J. prev. soc. Med., $12,94$.

HiLls, M. (1969). On looking at large correlation matrices. Biometrika. In press.

Hulton Readership SuRVeY (1948). Supplementary Tables.

KoBAYASH, J. (1957). On geographical relationship between the chemical nature of river water and deathrate from apoplexy. Preliminary report. Ber. Ohara Inst. landw Biol., 11, 12.

MINISTRY OF TRANSPORT (1961). Road Motor Vehicles. H.M.S.O., London.

MoRris, J. N. (1964). Uses of Epidemiology, 2nd ed. Livingstone, Edinburgh and London.

-, Crawford, M. D., and Heady, J. A. (1961). Hardness of local water-supplies and mortality from cardiovascular disease. Lancet, 1, 860.

(1962). Hardness of local water-supplies and mortality from cardiovascular disease. Ibid, 2, 506.

- and Trtmuss, R. M. (1944). Health and social change I. The recent history of rheumatic heart disease. Med. Offr, 72, 69, 77, 85; and unpublished data. 
Registrar-General (1938). Decennial Supplement, England and Wales, 1931. Part IIa: Occupational Mortality. H.M.S.O., London.

- (1933). Decennial Supplement, England and Wales, 1921. Part III: Estimates of Population Statistics of Marriages, Births and Deaths, 1911-1920. H.M.S.O., London.

- (1952). Decennial Supplement, England and Wales, 1931. Part III: Estimates of Population Statistics of Marriages, Births and Deaths, 1921-1930. H.M.S.O., London.

Registrar-General Census 1951 and 1961, England and Wales; County Reports, Housing Tables, Occupapation Tables. H.M.S.O., London.

REgistrar-General, Statistical Review of England and Wales, 1948-54 and 1958-64; part 1 (tables, medical). H.M.S.O., London; and unpublished data.

ROYAL COMmission ON LOCAL GOVERNMENT IN ENGLAND (1968). Research studies, no. 5. H.M.S.O., London.

SCHROEDER, H. A. (1960a). Relation between mortality from cardiovascular disease and treated water supplies. J. Amer. med. Ass., 172, 1902.

- (1960b). Relations between hardness of water and death rates from certain chronic and degenerative diseases in the United States. J. chron. Dis., 12, 586.

- (1966). Municipal drinking water and cardiovascular death rates. J. Amer. med. Ass., 195, 81.

Stocks, P. (1947). Regional and local differences in cancer death rates. General Register Office, Studies on Medical and Population Subjects, No. 1, H.M.S.O. London.

- (1960). On the relations between atmospheric pollution in urban and rural localities and mortality from cancer, bronchitis, and pneumonia, with particular reference to $3: 4$ benzopyrene, beryllium, molybdenum, vanadium and arsenic. Brit. J. Cancer, 14, 397.

(1962). On the death rates from cancer of the stomach and respiratory diseases in 1949-53, among coal miners and other male residents in counties of England and Wales. Ibid., 16, 592.

- (1966). Recent epidemiological studies of lung cancer mortality, cigarette smoking and air pollution, with discussion of a new hypothesis of causation. Ibid., $20,595$.

- (1967). Lung cancer and bronchitis in relation to cigarette smoking and fuel consumption in twenty countries. Brit. J. prev. soc. Med., 21, 181.

TAKaHASH, E. (1967). Geographic distribution of mortality rate from cerebrovascular disease in European countries. Tohoku J. exp. Med., 92, 345.

Tobacco Research Council. Personal communication.

WILKINS, L. T. (1952). Estimating the social class of towns. Appl. Statist., 1, 27.
APPENDIX PARTICULARS OF 61 COUNTY BOROUGHS OVER 80,000
TOTAL POPULATION IN 1961

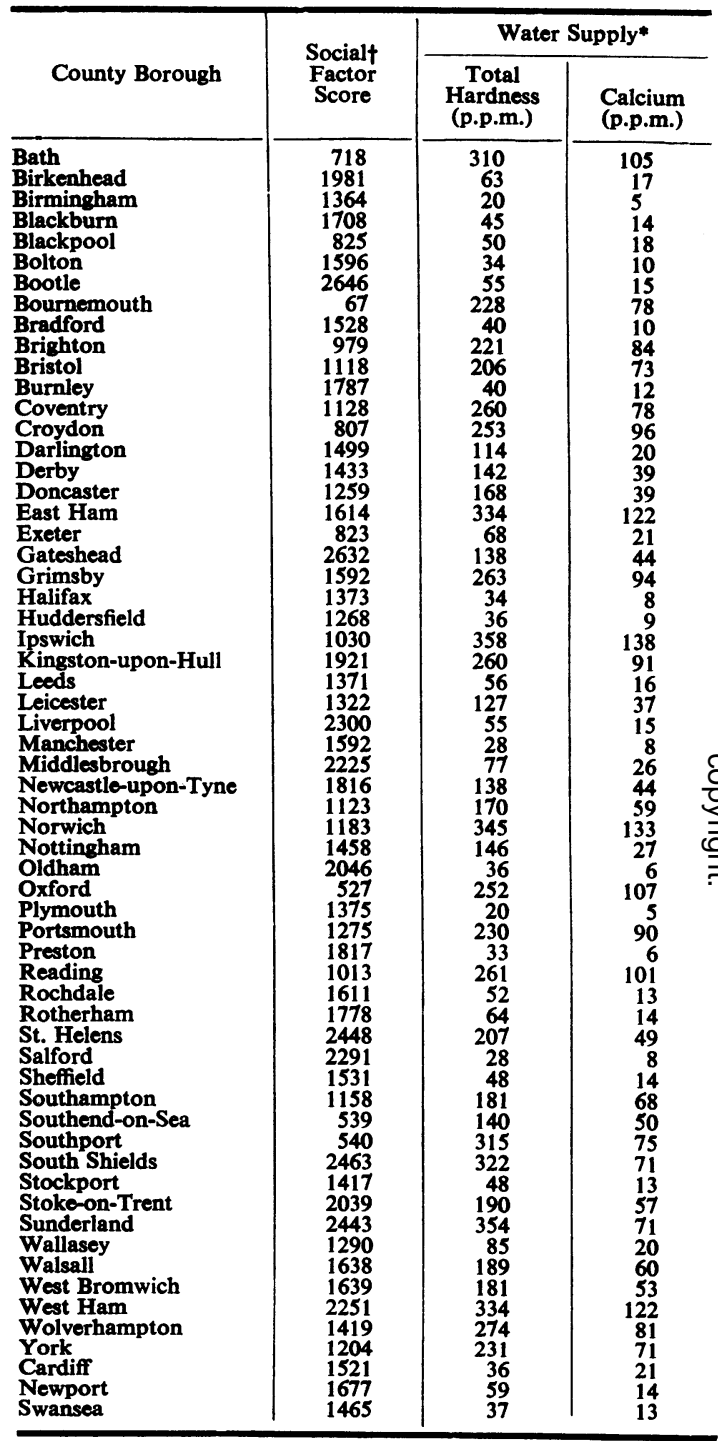

tA weighted linear combination of the nine indices described in Table IV (arbitrary units - the 'worse' towns have higher scores).

-The values shown are estimates for the period around 196i; in towns with multiple sources of supply the average for each source was weighted by the proportion of the population it served to give an overall local estimate (Crawford, Gardner, and Morris, 1968b).

The death rates used in this study are not given here. Rates for the earlier period were published in The Registrar-General's 'Quarterly Return No. 432, December, 1956. Appendix D', and figures for the five years 1959-63 in The Registrar-General's 'Decennial Supplement, England and Wales, 1961. Area Mortality, Tables' (1967). 